regulation of limited sanity which were discussed in the Ukrainian parliament during the adoption of the code. Taking into account the achieved level of science of criminal law and forensic psychiatry, the formula of limited sanity has been studied. Additional arguments were put forward in favor of recognizing exclusively mental disorders as a medical criterion, which fully complies with the provisions of the Law of Ukraine «On Psychiatric Care» and the International Statistical Classification of Diseases and Problems Related to Health (ICD-10). Based on the concept of human consciousness formed by science and expert practice, it is proposed to preserve the current description of the intellectual feature of the psychological criterion. The unity of consciousness and will is emphasized, which allows us to propose a change in the approach to describing the intellectual and volitional sign of this criterion. Taking into account the ambiguous approach in science to accounting for limited sanity when imposing a sentence, it is proposed to discuss the optional meaning of this circumstance when mitigating punishment. Attention is drawn to the inadmissibility of maintaining compulsory psychiatric care to the category of criminals recognized as having limited sanity. In support of this, the provisions of national and international legislation are cited, according to which, outside the criminal law field, the provision of such assistance forcibly to persons who do not have a severe mental disorder is strictly prohibited.

Keywords: limited sanity, criteria, signs, punishment, compulsory psychiatric care.

DOI: $10.33766 / 2524-0323.92 .152-166$

УДК 343. 7(73+477)

Д. В. Каменський,

доктор юридичних наук, доцент, завідувач кафедри правознавства

Бердянського державного педагогічного університету (м. Бердянськ, Україна)

e-mail: dm.kamensky@gmail.com iD https://orcid.org/0000-0002-3610-2514

\title{
УКЛАДАННЯ УГОД ПРО ВИЗНАННЯ ВИНУВАТОСТІ У ВЧИНЕННІ ЕКОНОМІЧНИХ ПРАВОПОРУШЕНЬ: ВІТЧИЗНЯНИЙ ТА АМЕРИКАНСЬКИЙ ПІДХОДИ
}

У статті в компаративістському режимі визначено юридичні підстави та охарактеризовано правозастосовні нюанси укладання угод про визнання винуватості у вчиненні економічних правопорушень. Розкрито причини усталеної, поширеної (до 95 \% від загальної кількості порушених кримінальних справ) практики американського правозастосувача в частині укладання угод про визнання винуватості, показано переваги такого інституту саме в аспекті протидії держави злочинам економічного характеру. На цьому тлі вітчизняний аналог, запроваджений у правову систему відносно нещодавно, у зв' язку з ухваленням чинного КПК, наразі сприймається яК нерозвинений, відносно непоширений інститут (до 15-20 \% від загальної кількості порушених кримінальних справ), водночас маючи значний потенціал для подальшого вдосконалення.

Обгрунтовано авторську позищію про те, що норма ст. 389-1 КК, присвячена відповідальності за умисне невиконання угоди про примирення або про визнання невинуватості, є проявом помилкової криміналізації та повинна бути виключена.

(C) Каменський Д. В., 2020 
Ключові слова: угода про визнання винуватості, економічне правопорушення, кримінальна відповідальність, покарання, правозастосовна практика, процесуальний статус.

Постановка проблеми. Інститут угод у кримінальному судочинстві $є$ втіленням конщепції відновлювального правосуддя, хоча й має певні відмінності з ним. За своїм нормативним «дизайном» цей інститут покликаний сприяти досягненню консенсусу між сторонами угоди, урегулюванню соціального конфлікту. Головна мета інституту угод у кримінальному провадженні полягає не у встановленні істини у справі, а в задоволенні інтересів сторін [1, с. 289].

У запропонованій статті буде критично проаналізовано напрацьований вітчизняний та американський досвід у контексті нормативної регламентації та практики застосування інституту угод про визнання винуватості. Вибір автором саме американської моделі був невипадковим, адже Сполучені Штати перші у світі запровадили в межах національної системи кримінальної юстиції механізми альтернативного правосуддя на підставі угоди між обвинуваченим та прокурором: визнання вини в інкримінованому злочині «в обмін» на більш м'яке покарання, затверджене судом без традищійного розгляду кримінальної справи.

Варто зазначити, що в США, на відміну від держав континентального права, у т.ч. України, спостерігається щільний взаємозв'язок між власне положеннями матеріального кримінального права та кримінально-процесуальними нормами (американські правники ще називають їх процедурними нормами). А тому, враховуючи цю особливість, уважаю за доцільне охарактеризувати таку поширену на практиці підставу звільнення від покарання економічних злочинців, як угода про визнання винуватості. До слова, автор статті уже частково звертався до зазначеної проблематики в одній із своїх попередніх робіт [2, с. 274- 276].

Аналіз останніх досліджень і публікацій. Проблематика матеріальної та процесуальної регламентації інституту угод про визнання винуватості активно висвітлюється в роботах вітчизняних та американських науковців, хоча й в помітно меншому обсязі в контексті застосування кримінально-правового впливу на економічних правопорушників. Серед дослідників відповідного напряму кримінально-правового регулювання варто виокремити О. Дудорова, В. Навроцького, І. Давидович, М. Лотоцького, Р. Новака, М. Сіроткіної, Р. Бабанли, С. Ященко, Л. Дервана, А. Елліса, Е. Подгор, П. Ларкіна. Натомість спостерігається брак наукової уваги саме до компаративістського аналізу режимів укладання відповідних угод, зокрема в контексті кримінально-правової охорони відносин ринкової економіки.

Формулювання цілей. Із огляду на зазначене, мета статті полягає в критичному компаративістському аналізі юридичних підстав та порядку укладання угод про визнання винуватості у вчиненні економічних правопорушень в Україні та США. Важливим завданням у зв'язку з цим є визначення того, чи відповідає практика укладання відповідного виду процесуальних угод завданням кримінально-правового регулювання взагалі та відносин ринкової економіки зокрема. Також необхідним є висвітлення процесуальних та безпосередньо правозастосовних аспектів укладання та реалізації положень таких угод. 
Виклад основного матеріалу. У США сфера застосування угод про визнання винуватості є традиційно широкою та охоплює практично всі види економічних злочинів. До того ж, на відміну від української практики укладання угод про визнання винуватості обвинуваченим, яка тільки-но формується з урахуванням власних спроб і помилок, у США укладання таких процесуальних угод між сторонами обвинувачення та захисту виступає ефективним важелем не лише для встановлення вини порушника 3 його власною допомогою в тих випадках, коли 3 об'єктивних причин правоохоронцям важко встановити вину. Другою і не менш важливою функцією таких угод є отримання від обвинуваченого важливої інкримінуючої інформації про інші латентні злочини (зокрема, у сфері економіки) в обмін на особисті кримінально-правові преференщії. Таким чином, для федеральних агентів укладання угод про визнання винуватості стає умовним ключем для успішного переслідування інших економічних злочинів, що є тим більш необхідним за умови хронічного браку кадрових і матеріальних ресурсів.

У контексті ознайомлення з окресленим блоком питань заслуговують на увагу деякі критичні міркування щодо застосування угод про визнання винуватості, висловлені В. Навроцьким ще до законодавчого запровадження цього кримінальнопроцесуального інституту в Україні. Зокрема, особливу увагу привертають аргументи вченого contra цих угод із позицій теорії кваліфікації злочинів. Автор констатує загальновизнаний підхід, відповідно до якого діяння спочатку піддається кримінально-правовій кваліфікації, тобто встановлюються ознаки відповідного злочину, передбачені диспозицією статті кримінального закону, і лише після цього призначається покарання в межах санкції відповідної статті Особливої частини КК. Натомість при укладанні угоди все відбувається навпаки, адже предметом процесуальних «торгів» виступає передусім потенційне покарання. В. Навроцький влучно додає: «Під покарання «підганяється» обсяг обвинувачення, кваліфікація вчиненого. Фактично при кваліфікації посягання прокурор, який є учасником угоди, суд, який іï приймає і санкщіонує, виходять не з ознак злочину, що закріплені в диспозищії статті, а із санкцій статей Особливої частини». Справедливим видається критичний коментар вченого про відсутність у разі застосування угод про визнання усталеного правила про єдність кваліфікації, що полягає в однаковому вирішенні питань кримінально-правової кваліфікації на всій території держави та єдиної юридичної ощінки поведінки будь-якої особи в разі вчинення тотожних діянь. Український криміналіст вважає, що укладання угод про визнання винуватості шкодить таким принципам кримінально-правової кваліфікації як об'єктивність, точність, повнота, стабільність і, головне, законність [3, с. 507-509].

I. Давидович задається практично важливим питанням: чи можуть сторони угоди про примирення або про визнання винуватості визначати покарання, а суди - затверджувати відповідні угоди, якщо окремі питання з приводу міри покарання особі в конкретній кримінально-правовій ситуації не врегульовані на нормативному рівні, а також якщо відсутні правозастосовні орієнтири для їх вирішення, адже, як відомо, значна частина питань, пов' язаних із призначенням покарання, залишається нерозглянутою? Зокрема, на законодавчому рівні не вирі- 
шене питання про мінімальну межу покарання за незакінчений злочин, про можливість застосування положень частин 2, 3 ст. 68 та ст. 69-1 КК до додаткових покарань, про співвідношення окремих видів пом'якшення покарання, про максимальну межу остаточного покарання за сукупністю злочинів у вигляді штрафу, якщо за окремі злочини штраф призначався з виходом за межі санкції в порядку, передбаченому ч. 2 ст. 53 КК тощо [4, с. 116].

Варто згадати також про висловлене у юридичній літературі застереження про те, що вітчизняній судовій практиці призначення покарання притаманна тенденція призначення покарань ближче до нижньої межі санкції за відсутності обтяжуючих обставин; аналогічна тенденція спостерігається також у контексті призначення покарання на підставі угод, оскільки цей вид кримінального провадження здебільшого і розрахований на обрання м'яких видів покарань із тих, які передбачені санкцією статті кримінального закону. Ураховуючи фактичну та юридичну відсутність ролі суду у вирішенні питання щодо обрання виду та міри покарання у провадженнях на підставі угод, вагомого значення в таких провадженнях набувають питання регламентованих меж покарання [5, с. 331, 342].

Принагідно звернусь до актуальної статистики. Відповідно до опублікованої Верховним Судом статистичної інформації про розгляд судами першої та апеляційної інстанцій кримінальних проваджень та справ про адміністративні правопорушення упродовж 9 місяців 2018-2019 років, усього за 9 місяців 2018 р. було розглянуто із затвердженням угод 12 тис. 597 кримінальних проваджень, що становить 21,8 \% від загальної кількості розглянутих кримінальних проваджень з ухваленням вироку (57 тис. 844). За аналогічний період 2019 року із затвердженням угод було розглянуто 12 тис. 441 проваджень, що становить 22,5 \% від кількості розглянутих кримінальних проваджень з ухваленням вироку (55 тис. 271). Притому, упродовж 9 місяців 2018 та 2019 років судами було відмовлено в затвердженні угоди й повернуто прокурору для продовження досудового розслідування 206 i 238 разів відповідно [6].

Як можна побачити з наведених цифр, інститут угод про визнання винуватості досить впевнено «вкоренився» у вітчизняній системі кримінального судочинства та стабільно охоплює п'яту частину всіх розглянутих судами першої інстанщії кримінальних проваджень.

Повертаючись до американських реалій, зазначу, що за даними судової статистики, майже 97 \% (!) кримінальних справ про економічні злочини в цій державі завершуються саме підписанням угоди про визнання порушниками своєї вини. Американські фахівці небезпідставно порівнюють юридичну природу угод про визнання винуватості 3 цивільно-правовими угодами (контрактами). Справді, така кримінально-процесуальна угода укладається в письмовій формі між двома сторонами - прокурором та обвинуваченим, а також затверджується судом, створюючи в такий спосіб новий юридичний факт [7, с. 1].

Наведена цифра у 97 \% є вражаючою і водночас спонукає замислитись над причинами такої великої кількості випадків вирішення питань кримінальної відповідальності «поза судом». Авторитетне ділове видання «Forbes», так само, як і 
більшість фахівців, сходяться в тому, що головна причина цього полягає не у високому ризику отримання обвинувального вироку в суді, хоча успішність діяльності державних обвинувачів традиційно оцінюється приблизно на рівні 90 \% від ухвалених обвинувальних вироків. Навпаки, головна причина є в принципі банальною й безпосередньо корелюється з основним предметом економічних злочинів - грошовими коштами. Наприклад, декілька гучних кримінальних процесів про інсайдерську торгівлю цінними паперами, які відбулись у першому десятиріччі цього століття, «коштували» обвинуваченим від 30 до 50 млн дол. у частині витрат на правову допомогу. Очевидно, що далеко не кожен голова правління корпорації може «дозволити» собі спростувати всі обвинувачення в суді [8]. Така «монетизація» системи угод про визнання винуватості, особливо в економічних злочинах, залишається предметом гострої критики з боку правозахисників, науковців і суддів.

Для порівняння, у вступній частині здійсненого свого часу ВССУ узагальнення судової практики щодо здійснення кримінального провадження на підставі угод наводилась така статистика: станом на 1 січня 2014 р. суди загальної юрисдикції розглянули 22 тис. 653 угод, із них 11 тис. 512 - про примирення та 11 тис. 141 - про визнання винуватості. Зі статистичної інформації вбачається збереження тенденщії до поширення практики застосування інституту угод у кримінальному судочинстві. Аналіз динаміки показників застосування положень КПК у судовій практищі свідчить про те, що кількість затверджених вироком угод $є$ в цілому сталою, без суттєвих коливань, і становить у середньому майже 3 тис. затверджених угод на місяць, тоді як кількість постановлених судом судових рішень про відмову в затвердженні угоди коливається в межах від 70 до 250 ухвал на місяць. Із приводу укладання відповідних процесуальних угод ВССУ влучно резюмував, що, незважаючи на позитивну динаміку затверджених вироків на підставі угод та з огляду на те, що цей інститут є новим для кримінального судочинства, його механізм ще не відпрацьовано судовою практикою та достатньою мірою не досліджено науковою доктриною. Із урахуванням цього, а також беручи до уваги появу нових формулювань, підходів та оціночних категорій у новому КПК, актуальним і необхідним є вивчення та узагальнення судової практики здійснення кримінального провадження на підставі угод [9].

Чимало американських дослідників сходяться в тому, що своїм «провалом» у частині кримінально-правового регулювання Акт Сарбейнса-Окслі «винен» усталеному в американській системі кримінальної юстиції і водночас найбільш поширеному в правозастосовній практиці інституту укладання угод про визнання винуватості. Дещо красномовно $з$ цього приводу висловився ВС США у справі «Lafler v. Cooper» (2012 р.), зазначивши, що сьогодні кримінальна юстиція - це здебільшого система процесуальних угод, а не система судових процесів. 97 \% федеральних вироків та 94 \% вироків у штатах є результатом укладання угод про визнання засудженим своєї вини [10].

Хоча цей інститут бере свій початок ще з англійського загального права, історично він почав активно застосовуватися на території США лише в XX столітті. Так 
у 1900-х роках «торгівля справедливістю» набула помітного корупщійного забарвлення, оскільки судді та адвокати активно «обмінювали» поблажливі вироки на гроші (мимоволі напрошуються паралелі з корупщійними проявами в правоохоронній сфері нашої держави). Пізніше, у 20-х роках минулого століття, із ухваленням нових актів кримінального законодавства, стрімким зростанням злочинності в період дії Сухого закону, а також обмеженістю правоохоронних ресурсів інструмент укладання угод про визнання винуватості став життєво необхідним для того, щоб система кримінальної юстиції продовжувала функціонувати [11, с. 193].

Коментатори звертають увагу на те, що історично поширеність угод про визнання винуватості стала прямим системним наслідком необгрунтованої криміналізації суспільної поведінки, яка є властивою усталеній практиці американського законодавця. До слова, якщо у 1908 році лише половина кримінальних справ завершувались винесенням угод про визнання винуватості, то в 1925 році, коли федеральний кримінальний закон було суттево розширено за рахунок «антиалкогольних» та «антигангстерських» заборон, цей показник уже сягнув відмітки в $90 \%$. Цікаво, що, незважаючи на невизнання інституту укладання угод про визнання винуватості федеральними апеляційними судами ще в другій половині XIX ст. та активне застосування цього інституту на практиці уже з початку XX ст., лише в 1970 році його було визнано таким, що відповідає положенням Конституції США. Тоді ВС США у справі «Brady v. United States» (1970р.) своїм рішенням визнав законність визнання особою своєї вини в обмін на зменшення розміру покарання. Під час ретельного обгрунтування своєї позищії Суд наголосив на перевагах таких угод як для самого обвинуваченого, так і для державного обвинувачення. Зокрема, для винної особи така угода несе можливість одразу почати відбувати покарання - вона перестає бути в центрі уваги суспільства, а також уникає всіх фінансових, організаційних, часових та інших негативних обставин, які традиційно супроводжують стандартний судовий процес. Своєю чергою, держава виграє за рахунок гарантованого і більш швидкого, економного застосування кримінального покарання до винної особи, що сприяє більш ефективній реалізації цілей покарання. Також за рахунок таких угод відбувається реальна і значна економія правоохоронних ресурсів держави, які відтепер можна спрямувати на вирішення тих кримінальних справ, у яких доказів вини підсудного значно менше або існують серйозні підстави побоюватися, що держава в особі прокуратури не зможе справитись із тягарем доказування. Далі Суд зробив слушне застереження про те, що визнання вини, так само як і традиційний варіант розгляду кримінальної справи, не повинен переходити певну правову межу, адже власне інкримінування чи притягнення завідомо невинного до кримінальної відповідальності є неприпустимими за будь-яких умов [12].

Американський учений Л. Дерван зауважує, що за сучасного дизайну системи кримінальної юстиції в США угоди про визнання вини та феномен надмірної криміналізації існують нерозривно, вони є взаємно обумовлюючими. Існування великої кількості кримінально-правових статутів, які нерідко дублюють один одного, створюючи для практики відверто колізійні ситуації, дають держав- 
ному обвинуваченню широкий простір для процесуальних маневрів. А тому, обираючи ті чи інші умови угоди про визнання вини та реалізуючи свої дискреційні повноваження, прокурор може керуватись широким спектром чинників (міркувань) - рух конкретної кримінальної справи, наявність чи зміст доказової бази, політичний або суспільний тиск, власна репутація, стратегічні та процесуальні переваги обраного формату угоди про визнання вини тощо. За результатами проведеного дослідження існуючої системи угод про визнання винуватості та одночасно надмірної криміналізації протиправної поведінки, автор робить висновок про те, що система чітко сформульованих, зрозумілих заборон, система об'єктивних санкцій по суті не вигідна ані законодавцю, ані правоохоронщям, ані судам $[13$, с. 51, 58]. Про пересічних громадян, які час від часу потрапляють у пастку заплутаного кримінально-правового «лабіринту», узагалі не йдеться.

Можна припустити, що Акт Сарбейнса-Окслі, а точніше, його кримінальноправова складова, своєю дещо невтішною реалізацією на практиці винна, з одного боку, поширеній практиці укладання угод про визнання винуватості, а з іншого казуїстичності американського кримінального законодавства. Конгрес «уклав» у руки федеральних прокурорів нові можливості для істотного розширення меж кримінальної відповідальності за шахрайські зловживання в корпоративному середовищі шляхом, а також збільшив розмір покарання за них. Своєю чергою, державні обвинувачі, замість того, щоб агресивно реалізовувати задум законодавця про масштабні кримінальні переслідування корпоративних шахраїв аж до винесення їм обвинувальних вироків, використали новели кримінального закону посвоєму - як чергову «розмінну монету» в перемовинах з правопорушниками під час укладання угод про визнання винуватості. Тут мимоволі пригадуються популярні нарікання в бік українського права взагалі і кримінального зокрема: закони у нас загалом непогані, а от із їх виконанням є серйозні проблеми. Ситуація, яка склалась із наведеним вище федеральним актом США, лише наголошує на тому, що ризики серйозної системної розбіжності між законом та його втіленням у життя не оминули й держави з білыш розвинутими системами права.

Якщо узагальнено охарактеризувати угоду про визнання вини, то ії кримінально-правовий зміст може бути подано у вигляді своєрідного компромісу інтересів: обвинувачений погоджується визнати себе винним у вчиненні одного чи декількох епізодів злочинної діяльності; в обмін на це сторона обвинувачення погоджується виключити з обвинувального висновку декілька пунктів обвинувачення і в подальшому не продовжувати кримінальне переслідування за ними. Також сторона обвинувачення в аналізованій угоді може пообіцяти обвинуваченому зменшити вид та розмір покарання, на якому наполягатиме під час відповідного етапу судового розгляду справи.

Так само, як і щодо будь-якої юридичної угоди (контракту), на практиці можуть виникнути ситуації, коли угода про визнання винуватості порушується однією зі сторін, які іiі уклали. Ураховуючи, що цей вид процесуальних угод безпосередньо охоплює конституційні права американських громадян, порушення іï умов може викликати серйозні зауваження на адресу дотримання конституцій- 
ного імперативу належної правової процедури (англ. - due process clause). Зокрема, якщо засуджений істотно порушує вимоги угоди про визнання винуватості, сторона обвинувачення також автоматично звільняється від обов' язку ії дотримуватись. Відповідно, якщо обвинувачений порушує хоча б одну з істотних умов такої угоди, суд уже не буде «зв' язаний» узгодженим сторонами вироком. Водночас, якщо обвинуваченого не попередили про те, що порушення угоди може призвести до призначення йому більш суворого покарання, таке покарання вважатиметься прямим порушенням конституційної гарантії належної правової процедури (англ. - due process clause). Якщо обвинувачений порушив процесуальну угоду, то його судитимуть знову, що не визнається порушенням заборони на притягнення до кримінальної відповідальності двічі (англ. - double jeopardy clause). Таким чином, у разі порушення умов угоди, прокурор може знову порушити кримінальну справу та наполягати на більш суворій формулі обвинувачення, аніж та, яка була зазначена в тепер уже недійсній угоді [14, с. 1126].

Аналогічний підхід втілено у вітчизняному кримінально-процесуальному законодавстві. Зокрема, у ч.1 ст. 476 КПК зазначено, що в разі невиконання угоди про примирення або про визнання винуватості, потерпілий чи прокурор, відповідно, мають право звернутися до суду, який затвердив таку угоду, із клопотанням про скасування вироку. Суд своєю ухвалою скасовує вирок, яким затверджена угода, якщо особа, яка звернулася з відповідним клопотанням, доведе, що засуджений не виконав умови угоди (ч.3 ст. 476 КПК). Після скасування вироку буде призначений судовий розгляд у загальному порядку.

Умисне невиконання засудженим угоди про визнання винуватості (а так само угоди про примирення) визнається злочином на підставі ст. 389-1 КК. A priori юридичною підставою для запровадження цієї заборони стала ч.5 ст. 476 КПК, у якій зазначено, що умисне невиконання угоди є підставою для притягнення особи до відповідальності, встановленої законом.

Цей злочин вважається закінченим із моменту невиконання засудженим хоча б однієї з істотних умов, зазначених в угоді, виконання якої залежить саме від засудженого, коли це створює істотну шкоду для інтересів правосуддя (відповідне діяння включене до розділу XVIII Особливої частини КК «Злочини проти правосуддя»). Ідеться про випадки, коли не виконано саме ті істотні умови угоди, щодо яких вона укладалась, зокрема коли засуджений: не відшкодував шкоду потерпілому, не вчинив на користь потерпілого інших відповідних дій, припинив співпрацю у викритті кримінального правопорушення, вчиненого іншою особою. Притому, оскільки ч.4 ст. 469 КПК не забороняє укладення угоди в злочині, передбаченому ст. 389-1 КК, існує можливість укласти угоду про виконання засудженим угоди про визнання винуватості [15, с. 1227].

У дисертаційному дослідженні, присвяченому проблемам кримінальної відповідальності за ст. 389-1 КК, С. О. Ященко припускає, що в практичній діяльності можуть бути випадки повторного умисного невиконання угоди про визнання винуватості, після засудження особи на підставі такої угоди за вчинення злочину, передбаченого безпосередньо ст. 389-1 КК. Тому вчинення упродовж строку судимості повторно (знову) злочину, передбаченого ст. 389-1 KК, потрібно розглядати як 
його кваліфікуючу ознаку. Через те дисертантка пропонує законодавчі приписи ст. 389-1 КК доповнити частиною другою, яка би передбачала білыш сувору відповідальність у таких випадках [16, с. 10]. Не піддаючи сумніву логіку викладених міркувань, водночас критично оцінюю таку собі правозастосовну «тавтологію»: навіщо нормативно давати правозастосувачу можливість «ставати на ті ж самі граблі», удруге (утретє тощо) укладати угоду про визнання винуватості в порушенні вимог раніше укладеної угоди про визнання винуватості? Очевидно, що текст ст. 389-1 КК містить низку серйозних змістових недоліків.

Вважаю, що описані вище наслідки невиконання угоди про примирення або про визнання винуватості, закріплені в ч.3 ст. 476 КПК, цілком спроможні виконувати відновлювальну та компенсаторну функцію в разі порушення засудженим вимог угоди. «Порушив угоду - отримав вирок на загальних умовах» - такий правозастосовний підхід здатен, на мій погляд, забезпечити, із одного боку, повагу та орієнтованість на виконання умов угоди з боку засудженого, а з іншого - гарантує призначення судом більш суворого покарання в разі невиконання таких умов.

Навіть більше, якщо тут провести умовні (і доречні) паралелі з інститутом звільнення засудженого від покарання з випробуванням (ст.ст. 75-79 КК), то можна побачити схожість у наслідках невиконання покладених судом на засудженого обов' язків (чи порушенням ним певних установлених умов). Зокрема, у ч.2 ст. 75 KК зазначено, що в разі якщо засуджений не виконує покладені на нього обов' язки або систематично вчинює правопорушення, які потягли за собою адміністративні стягнення і свідчать про його небажання стати на шлях виправлення, суд направляє засудженого для відбування призначеного покарання. А в разі вчинення засудженим протягом іспитового строку нового злочину суд призначає йому покарання за правилами, передбаченими в ст.ст. 71, 72 КК. Тобто відбувається, так би мовити, повернення до попередніх, «допривілейованих» кримінально-правових відносин між правопорушником і державою.

Схожий компенсаторний підхід втілено в американській правозастосовній практищі: якщо обвинувачений порушив відповідну процесуальну угоду, то, ураховуючи здебільшого «контрактний» (диспозитивний) підхід до інтерпретації змісту та умов таких угод, вона анулюється, а ії умови ігноруються - особу судитимуть знову на загальних умовах порядку із винесенням традиційного вироку.

Певні зауваження на адресу одночасного застосування ст. 389-1 КК та відповідної статті КК, якою передбачено злочин, щодо факту вчинення якого було укладено угоду про визнання винуватості, викликає й зміст ч.3 ст. 2 КК - ніхто не може бути притягнутий до кримінальної відповідальності за той самий злочин більше одного разу. Хоча юридично питання про подвійне інкримінування в подібних ситуаціях начебто виникати не повинно з огляду на різні ознаки відповідних складів злочинів у їхній сукупності, водночас серйозні застереження викликає та обставина, що невиконання авторизованих кримінальним процесуальним законодавством вимог (щодо обов' язкових умов відповідної угоди), пов' язаних із «первісним» злочином, вчинення якого, власне, і стало підставою для укладання угоди, стає юридичною підставою для притягнення до кримінальної відповідальності 
вже за новий злочин - умисне невиконання угоди про примирення або про визнання винуватості. Має місце, так би мовити, подвійна метаморфоза кримінальної відповідальності за, по суті, одиничний (первісний) злочин.

Наведені міркування спонукають висловити позищію про необхідність виключення ст. 389-1 із тексту КК.

Варто зазначити, що у вітчизняній юридичній літературі висловлюється також, так би мовити, гібридна позищія щодо окресленої декриміналізації, за якої пропонується відмовитись від кримінальної відповідальності за умисне невиконання засудженим угоди про визнання винуватості, водночас залишивши норму про невиконання угоди про примирення з потерпілим (у межах редакційно оновленої ст. 389-1 KK) [17, с. 14, 164]. Щоправда, аргументів на користь саме такого диференційованого підходу не пропонується.

Принагідно звернусь, спираючись на властиві цій монографії компаративістські підходи, до узагальнюючого аналізу теорії та практики укладання процесуальних угод на підставі спеціальних положень українського законодавства. Нагадаю, що Законом України від 13 квітня 2012 р. № 4652-VI «Про внесення змін до деяких законодавчих актів у зв' язку з прийняттям Кримінального процесуального кодексу України» статтю 65 КК було доповнено частиною п’ ятою наступного змісту: «У випадку затвердження вироком угоди про примирення або про визнання вини суд призначає покарання, узгоджене сторонами угоди». Як зазначає А. Хильченко, запровадження угод про примирення, зокрема в аспекті пеналізаційної практики, зміщує акценти кримінальної юстиції з так званого пунітивного (з англ. «punitive» - каральний) на відновлювально-компенсаційний (рестораторний) [18, с. 292].

Звернусь до типового прикладу на затвердження українськими судами угод про визнання винуватості між прокурором та обвинуваченим у справах про економічні злочини.

Подільський районний суд міста Києва визнав Н. винним у підробці офіційного документа та шахрайства $з$ фінансовими ресурсами. Н. замовив й отримав від невстановленої досудовим розслідуванням особи наперед підроблену довідку про доходи ТОВ «Чайка», видану на ім'я Н. Також, реалізуючи свій злочинний умисел, спрямований на використання завідомо підробленого документа, Н. надав працівнику філії ПАТ «Альфа Банк» наперед підроблену довідку про доходи, тим самим використавши завідомо підроблений документ. Причому, реалізуючи свій злочинний умисел, спрямований на отримання кредиту, Н. надав працівнику банку завідомо неправдиву інформацію про те, що він працює в ТОВ «Чайка» на посаді менеджера з продажу, та вніс до анкети-заяви в письмовій формі завідомо неправдиву інформацію про отримання заробітної плати в ТОВ «Чайка» у сумі 28 тис. 425 грн на отримання банківського кредиту.

Суд установив винуватість Н. у вчинені кримінальних правопорушень, передбачених ч. 4 ст. 358 КК, ч.5 ст. 27, ч. ст. 358 КК, ч.1 ст. 222 КК.

За результатами розгляду кримінальної справи суд ухвалив затвердити угоду про визнання винуватості, укладену між прокурором прокуратури Подільського району міста Києва та обвинуваченим Н. Було призначене узгоджене сторонами цієї угоди покарання: за ч.5 ст. 27, ч.1 ст. 358 КК - у виді штрафу в розмірі 
50 НМДГ; за ч. 4 ст. 358 КК - у виді 1 року 3 місяців обмеження волі; за ч. 1 ст. 222 КК - у виді штрафу в розмірі 1 тис. НМДГ.

На підставі ч.1 ст. 70 КК, за сукупністю злочинів шляхом поглинення менш суворого покарання білыш суворим, Н. було призначене остаточне покарання у виді 1 року 3 місяців обмеження волі. Згідно зі ст. 75 КК, Н. було звільнено від відбування призначеного покарання за умови, що протягом іспитового строку (1 рік і 6 місяців) він не вчинить нового злочину і виконає покладені на нього судом обов'язки. Також згідно з п.п. 2, 3, 4 ч.1 ст. 76 КК, на Н. були покладені такі обов' язки: не виїжджати за межі України на постійне проживання без дозволу кримінально-виконавчої інспекції, повідомляти кримінально-виконавчу інспекцію про зміну місця проживання, роботи, навчання; періодично з' являтися для реєстрації в кримінально-виконавчу інспекцію [19].

Із цього дещо рутинного для досліджуваної категорії кримінальних справ прикладу з очевидністю випливає висновок про надмірну гуманність фактично призначеного покарання. Справді, у цій справі звільнення від покарання з випробуванням «нівелювало» навіть менш суворе покарання у виді штрафу, яке, на мій погляд, (принаймні в розмірі 50 НМДГ), було би цілком доречним. Принаймні в багатьох інших кримінальних справах про господарські злочини, які завершились укладенням таких угод, до засудженого de jure i de facto застосовується покарання у виді реальної сплати кримінального штрафу в значних розмірах. На цьому тлі узгоджене сторонами в згаданій кримінальній справі покарання сприймається як дещо несправжнє, фейкове.

Висновки. У цій статті з урахуванням порівняльно-правового методу було досліджено складну, подекуди контраверсійну, матеріально-процесуальну природу угод про визнання винуватості за законодавством України та США, а також висвітлено практичні аспекти їхнього застосування судами. Американський підхід у цій сфері правозастосування визнано більш прагматичним: він оптимально впливає на реалізацію завдань держави щодо кримінально-правового регулювання, дозволяє враховувати каральні, превентивні та заохочувальні функції кримінального закону під час переслідування економічних правопорушників.

Також аргументовано, що норма КК (ст. 389-1) про умисне невиконання угоди про примирення або про визнання невинуватості є проявом помилкової криміналізащії та має бути виключена. Описані в ч.3 ст. 476 КПК наслідки невиконання такої угоди цілком спроможні виконувати відновлювальну та компенсаторну функції в разі порушення засудженим вимог угоди. Практика призначення реального покарання на підставі обвинувального вироку, винесеного внаслідок порушення угоди, здатна забезпечити, з одного боку, повагу засудженого до умов угоди, а з іншого - гарантувати призначення судом білыш суворого покарання в разі невиконання таких умов.

Перспективним напрямом подальших наукових розробок у запропонованому дискурсі видається вивчення, з урахуванням результатів фахових емпіричних досліджень, динаміки та якості укладання угод про визнання винуватості, а також виявлення системних загроз, у т.ч. корупщіогенних чинників, пов' язаних із 
суто формальним, без урахування цілей і принципів кримінально-правового регулювання, які заважають повноцінному розвитку цього напряму відновлювального правосуддя.

\section{Використані джерела:}

1. Лотоцький М. В. Угода про визнання винуватості: процесуальний порядок укладення. Актуальні проблеми вдосконалення чинного законодавства Украйни. 2013. Вип. 31. C. 288-298.

2. Каменський Д. В. Угода про визнання вини як підстава поліпшення правового становища податкового злочинця за федеральним законодавством США. Запорізъкі правовi читання: матеріали щорічної Міжнародної науково-практичної конференції, м. Запоріжжя, 17-18 травня 2007 р. / за заг. ред. С. М. Тимченка і Т. О. Коломоєць. Запоріжжя : ЗНУ, 2007. С. 274-276.

3. Навроцький В. 3 професорської шухляди. Івано-Франківськ : Фоліант, 2016. 705 с.

4. Давидович I. Деякі особливості призначення покарання на підставі угод. Підириємництво, господарство і право. 2013. № 5. С. 112-116.

5. Бабанли Р. Призначення покарання в Україні: теоретико-прикладні засади. Чернігі в: Десна Поліграф, 2019. 488 с.

6. Статистична інформація про розгляд судами першої та апеляційної інстанцій кримінальних проваджень та справ про адміністративні правопорушення упродовж 9 місяців 2018-2019 років. URL : https://supreme. court.gov.ua/userfiles/ media/9_mis_2018_ 2019_pokaznyky.pdf. (дата звернення: 02.12.2020).

7. Ellis A., Allenbaugh M. Plea Bargained v. Open Pleas: What the Data Reveal. White-Collar Crime. Westlaw Journal. 2017. № 7. Volume 31. P. 1-6.

8. Pavlo W. The High Cost Of Mounting A White-Collar Criminal Defense. Forbes. May 30, 2013. URL : http://www.forbes.com/sites/walterpavlo/2013/05/30/the-high-cost-ofmounting-a-white-collar-criminal-defense/\#a6a21b4cec0b. (дата звернення: 02.12.2020).

9. Узагальнення судової практики здійснення кримінального провадження на підставі угод. URL : http://sc.gov.ua/ua/uzagalnennja_sudovoji_praktiki.html. (дата звернення: 02.12.2020).

10. Lafler v. Cooper, 132 S.Ct. 1376, 1388 (2012).

11. Каменський Д. В. Криміналізація окремих порушень у сфері економіки США: обгрунтована чи помилкова? Порівняльно-аналітичне право. 2015. №3. С. 187-191. URL : http:// www.pap.in.ua/3_2015/56.pdf (дата звернення: 02.12.2020).

12. Brady v. United States, 397 U.S. 742 (1970).

13. Dervan L. Bargained Justice: Plea Bargaining's Innocence Problem and the Brady Safety-Valve. Utah Law Review. 2012. № 51. P. 50-81.

14. Reddy D. Guilty Pleas and Practice. American Criminal Law Review. 1993. № 30. P. 11171137.

15. Науково-практичний коментар Кримінального кодексу України / за ред. М. I. Мельника, М. І. Хавронюка. 10-те вид., переробл. та допов. Київ : ВД «Дакор», 2018. 1360 с.

16. Ященко С. О. Кримінальна відповідальність за умисне невиконання угоди про примирення або про визнання винуватості : автореф. дис. ... канд. юрид. наук: 12.00.08. Харків, 2016. 18 с.

17. Потяк В. І. Кримінально-правове забезпечення охорони виконання угоди про примирення : дис. ... канд. юрид. наук: 12.00.08. Івано-Франківськ, 2019. 223 с.

18. Правовий вплив на НЕПравомірну поведінку: актуальні грані : монографія / за ред. проф. О. В. Козаченка, проф. Є. Л. Стрельцова. Миколаїв : Іліон, 2016. 768 с. 
19. Архів Подільского районного суду міста Києва. Справа № 758/1714/15-к. URL : http:/ / reyestr.court.gov.ua/Review/43251210. (дата звернення: 02.12.2020).

\section{References:}

1. Lototskyi, M. V. (2013). Uhoda pro vyznannia vynuvatosti: protsesualnyi poriadok ukladennia. Aktualni problemy vdoskonalennia chynnoho zakonodavstva Ukrainy - Current Problems of Improving Legislation of Ukraine, 31, 288-298. [in Ukrainian].

2. Kamenskyi, D. V. (2007). Uhoda pro vyznannia vyny yak pidstava polipshennia pravovoho stanovyshcha podatkovoho zlochyntsia za federalnym zakonodavstvom SShA. Zaporizki pravovi chytannia: materialy shchorichnoi Mizhnarodnoi naukovo-praktychnoi konferentsii, $m$. Zaporizhzhia, 17-18 travnia 2007 r. - Zaporizhia Legal Readings: Proceedings of the Annual International Scientific and Practical Conference, Zaporizhia, May 17-18, 2007. Zaporizhzhia: ZNU, 274-276. [in Ukrainian].

3. Navrotskyi, V. (2016). Z profesorskoi shukhliady. Ivano-Frankivsk : Foliant. [in Ukrainian].

4. Davydovych, I. (2013). Deiaki osoblyvosti pryznachennia pokarannia na pidstavi uhod. Pidpryiemnytstvo, hospodarstvo i pravo - Business, Economy and Law, 5, 112-116. [in Ukrainian].

5. Babanly, R. (2019). Pryznachennia pokarannia v Ukraini: teoretyko-prykladni zasady. Chernihiv : Desna Polihraf. [in Ukrainian].

6. Statystychna informatsiia pro rozghliad sudamy pershoi ta apeliatsiinoi instantsii kryminalnykh provadzhen ta sprav pro administratyvni pravoporushennia uprodovzh 9 misiatsiv 2018-2019 rokiv. Sait Verkhoonoho Sudu - Supreme Court. (2019) N. p. URL : https:/ / supreme.court.gov.ua/userfiles/media/9_mis_2018_2019_pokaznyky.pdf. [in Ukrainian].

7. Ellis, A., Allenbaugh, M. (2017). Plea Bargained v. Open Pleas: What the Data Reveal. White-Collar Crime. Westlaw Journal, Vol. 31, 7, 1-6. [in English].

8. Pavlo, W. The High Cost Of Mounting A White-Collar Criminal Defense. Forbes. May 30, 2013. (2013) URL : http://www.forbes.com/sites/walterpavlo/2013/05/30/the-high-costof-mounting-a-white-collar-criminal-defense/\#a6a21b4cec0b. [in English].

9. Uzahalnennia sudovoi praktyky zdiisnennia kryminalnoho provadzhennia na pidstavi uhod. Sait Verkhoonoho Sudu - Supreme Court. N. d. N. p. URL: http://sc.gov.ua/ua/uzagalnennja_sudovoji_praktiki.html. [in Ukrainian].

10. Lafler v. Cooper, 132 S. Ct. 1376, 1388 (2012) [in English].

11. Kamenskyi, D. V. (2015). Kryminalizatsiia okremykh porushen u sferi ekonomiky SShA: obgruntovana chy pomylkova? Porionialno-analitychne pravo - Comparative-Analytical Law, 3, 187-191. URL: http://www.pap.in.ua/3_2015/56.pdf. [in Ukrainian].

12. Brady v. United States, 397 U.S. 742 (1970). [in English].

13. Dervan, L. (2012). Bargained Justice: Plea Bargaining's Innocence Problem and the Brady Safety-Valve. Utah Law Review, 51, 50-81. [in English].

14. Reddy, D. (1993). Guilty Pleas and Practice. American Criminal Law Review, 30, 1117-113.7 [in English].

15. Naukovo-praktychnyi komentar Kryminalnoho kodeksu Ukrainy (2018). Melnyk, M. I., Khavroniuk, M. I. (Eds.). Kyiv : VD «Dakor». [in English].

16. Yashchenko, S. O. (2016). Kryminalna. Extended abstract of candidate's thesis. Kharkiv. [in Ukrainian].

17. Potiak, V. I. (2019). Kryminalno-pravove zabezpechennia okhorony vykonannia uhody pro prymyrennia. Extended abstract of candidate's thesis. Ivano-Frankivsk. [in Ukrainian].

18. Pravovyi vplyv na nepravomirnu povedinku: aktualni hrani: monohrafiia. (2016). Kozachenko, O.V., Streltsov, Ye. L. (Eds.). Mykolaiv : Ilion. [in Ukrainian]. 
19. Postanova Podilskoho raionnoho sudu mista Kyieva u spravi № 758/1714/15-k. N. d. N. p. Yedynyi derzhavnyi reiestr sudooykh rishen - Unified state register of court decisions. URL : http://reyestr.court.gov.ua/Review/43251210. [in Ukrainian].

Стаття надійшла до редколегії 03.12.2020

Каменский Д. В., доктор юридических наук, доцент, заведующий кафедрой правоведения

Бердянского государственного педагогического университета (г. Бердянск, Украина)

\section{ЗАКЛЮЧЕНИЕ СДЕЛОК О ПРИЗНАНИИ ВИНЫ В СОВЕРШЕНИИ ЭКОНОМИЧЕСКИХ ПРАВОНАРУШЕНИЙ: ОТЕЧЕСТВЕННЫЙ И АМЕРИКАНСКИЙ ПОДХОДЫ}

В статье в компаративистском режиме определены юридические основания и охарактеризованы правоприменительные аспекты заключения сделок о признании виновности в совершении экономических преступлений. Раскрыты причины сложившейся распространенной (до 95 \% от общего количества возбужденных уголовных дел) практики американского правоприменителя в частизаключения соглашений о признании виновности, показаны преимущества такого института именно в аспекте противодействия государства преступлениям экономического характера. На этом фоне отечественный аналог, введенный в правовую систему относительно недавно в связи с принятием действующего УПК, воспринимается как неразвитый относительно нераспространенный (до 1520 \% от общего количества возбужденных уголовных дел) институт, одновременно обладая значительным потенциалом для дальнейшего совершенствования.

Обоснованно авторскую позицию о том, что норма ст. 389-1 УК, посвященная ответственности за умышшенное невыполнение соглашения о примирении или о признании невиновности, является проявлением ошибочной криминализации и должна быть исключена.

Ключевые слова: соглашение о признании виновности, экономическоеправонарушение, уголовная ответственность, наказание, правоприменительная практика, процессуальный статус.

Kamensky D.,

Doctor of Law, Associate Professor,

Head of the Department of Law at Berdyansk State Pedagogical University

(Berdyansk, Ukraine)

\section{ENTERING INTO PLEA AGREEMENTS FOR COMITTING ECONOMIC OFFENSES: DOMESTIC AND AMERICAN APPROACHES}

Legal bases are defined and the law-enforcement nuances of the conclusion of plea agreements related to the commission of economic offenses are characterized in the scientific 
article, using the comparative method. The reasons for the well-established, widespread (up to $95 \%$ of the total number of criminal cases) practice of the American law enforcement in terms of concluding plea agreements are revealed, advantages of such institution in the aspect of counteracting economic crimes are demonstrated. Historical preconditions and genesis of this legal institution, which was first developed by the English common law, but then began to be actively used in the United States in the middle of the twentieth century, are revealed. Against this background, the domestic analogue, relatively recently introduced into the legal system, in connection with the adoption of the current CCP, is currently perceived as a somewhat underdeveloped, relatively uncommon (up to $15-20 \%$ of the total number of initiated criminal cases) institution, while possessing significant potential for law enforcement development.

It is stated that, as with any legal agreement (contract), in practice there are many situations, when a plea agreement is violated by one of its parties. Given that this type of procedural agreement directly covers the constitutional rights of American citizens, violation of its terms may raise serious objections to compliance with the constitutional imperative of due process.

The author's position that the Art. 389-1 of the Criminal Code, establishing criminal liability for intentional non-compliance with the conciliation agreement or the recognition of innocence, is a manifestation of erroneous criminalization and thus should be excluded. The practice of imposing a real sentence on the basis of a conviction for breach of agreement can, on the one hand, ensure that the convict respects the terms of the agreement and, on the other, guarantee that the court imposes a more severe punishment in case of non-compliance.

Keywords: plea agreement, economic offense, criminal liability, punishment, law enforcement practice, procedural status.

DOI: $10.33766 / 2524-0323.92 .166-176$

УДК 343.98

A. Kovalenko,

Phd in Law, Associate Professor in the Chair of Criminal-Law Disciplines Luhansk State University of Internal Affairs named after E. Didorenko (Sievierodonetsk, Ukraine) e-mail: new4or@gmail.com

iDhttps://orcid.org/0000-0003-3665-0147

\section{THE SOURCES OF FORENSIC RECOMMENDATIONS FOR COLLECTION, EXAMINATION AND USE OF EVIDENCE IN CRIMINAL PROCEEDINGS}

The article is devoted to identifying the main sources of forensic recommendations for the collection, examination and use of evidence in criminal proceedings. The author emphasizes that the relevance, sufficiency, practicality and methodological literacy of these recommendations should be ensured by the use of appropriate scientifically sound sources for their formation.

The sources of formation of such recommendations are: the most relevant provisions of forensic science; provisions of the legislation of Ukraine on criminal liability and provisions of the science of criminal law; provisions of the criminal procedural legislation of Ukraine and achievements of science of criminal procedure; legal positions formulated by the European Court of Human Rights; the practice of detection, investigation and trial of criminal offenses;

(C) Kovalenko A., 2020 